\title{
Assessment of absolute environmental sustainability in the built environment
}

Andersen, Camilla Ernst; Ohms, Pernille Krogh; Rasmussen, Freja Nygaard; Birgisdottir, Harpa; Birkved, Morten; Hauschild, Michael Zwicky; Ryberg, Morten

Published in:

Building and Environment

Link to article, DOI:

10.1016/j.buildenv.2019.106633

Publication date:

2020

Document Version

Peer reviewed version

Link back to DTU Orbit

Citation (APA):

Andersen, C. E., Ohms, P. K., Rasmussen, F. N., Birgisdottir, H., Birkved, M., Hauschild, M. Z., \& Ryberg, M. (2020). Assessment of absolute environmental sustainability in the built environment. Building and Environment, 171, [106633]. https://doi.org/10.1016/j.buildenv.2019.106633

\section{General rights}

Copyright and moral rights for the publications made accessible in the public portal are retained by the authors and/or other copyright owners and it is a condition of accessing publications that users recognise and abide by the legal requirements associated with these rights.

- Users may download and print one copy of any publication from the public portal for the purpose of private study or research.

- You may not further distribute the material or use it for any profit-making activity or commercial gain

- You may freely distribute the URL identifying the publication in the public portal 


\title{
Assessment of absolute environmental sustainability in the built environment
}

\author{
Camilla Ernst Andersen ${ }^{1}$, Pernille Ohms ${ }^{2}$, Freja Nygaard Rasmussen ${ }^{1}$, Harpa Birgisdottir ${ }^{1}$, \\ Morten Birkved ${ }^{3}$, Michael Hauschild ${ }^{2} \&$ Morten Ryberg ${ }^{2}$ \\ ${ }^{1}$ Danish Building Research Institute, Aalborg University, Copenhagen, Denmark \\ ${ }^{2}$ Technical University of Denmark, Department of Management Engineering, Kgs. Lyngby, \\ Denmark \\ ${ }^{3}$ Southern University of Denmark, Institute of Chemical Engineering, Biotechnology and \\ Environmental Technology, Odense, Denmark
}

\begin{abstract}
The purpose of this study is to investigate absolute environmental sustainability in the built environment, by assesing whether contemporary environmentally optimized approaches to building design, with their associated consumption of resources and subsequent emissions, can be considered within the carrying capacity of Earth Systems.
\end{abstract}

A life cycle assessment (LCA) was conducted for six dwellings to quantify their environmental footprints. Two methods for absolute environmental sustainability assessment were applied to the resulting life cycle inventories; one where the normalisation step applied normalisation factors reflecting carrying capacities of the Earth Systemand one where characterisation of elementary flows applied characterisation factors based on the Planetary Boundaries. For the assessment of environmental impact of each house in an absolute perspective, different sharing principles were applied to determine the share of the safe operating space that a single-family stand-alone dwelling should be assigned.

The study finds that the approaches tested in two of the dwellings, namely reducing the energy consumption and recycling and reusing materials have the greatest potential to reach an absolutely sustainable level of impact. The conclusions drawn are found to be dependent of the applied sharing principle used to assign a share of the safe operating space.

Nevertheless, as the results indicate that in our current society absolute sustainability for buildings still appear to be out of reach, even with the best attempts at sustainable building design. It is clear that to achieve e.g. lower energy consumption and a cleaner energy mix, action is needed by consumers and politicians alike. 


\section{KEYWORDS}

\section{Environmental performance of buildings, absolute sustainability assessment, carrying capacity, Planetary Boundaries}

\section{INTRODUCTION}

Today, there is very strong evidence of a causal connection between human activities and changes in the Earth's climate through increasing concentrations of $\mathrm{CO}_{2}, \mathrm{CH}_{4}$, and other greenhouse gases (GHGs) (Bindoff et al., 2013; Steffen et al., 2004). The emission of GHGs linked to human activities have increased since before the industrialisation and can be explained by a growth in both economy and population (IPCC, 2014). While the world population has increased more than 10 -fold to 7.6 billion over the past three centuries, the rate of consumption has increased even more dramatically (Steffen et al., 2015a, 2004). In fact, human activities have escalated so rapidly since the mid-20th century that the ecological stability of the 11,700-year-long period known as the Holocene may now be threatened (Rockström et al., 2009; Steffen et al., 2015b). This has led to efforts to quantify local, regional, and global environmental boundaries that should be respected to sustain the Holocene state of the global climate which is the only state that, for certain, can support contemporary human societies and the destabilization of which could be detrimental to humans (Steffen et al., 2015b). The Planetary Boundaries (PB) framework identified a set of bio- and geophysical Earth System processes that are considered key for maintaining the Holocene state, and identified thresholds or carrying capacities for each of the processes. The exact carrying capacity is not known due to natural variability and incomplete and hence uncertain scientific knowledge about the nature of the environmental systems and their underlying mechanisms (Rockström et al., 2009b). In the PB-framework, the uncertainty about the exact carrying capacity is indicated by a lower and an upper limit (see Figure 1). The PBs in the PB-framework were defined as the lower limit of the zone of uncertainty, thus applying a precautionary approach to maximize the certainty that carrying capacities are not exceeded (Rockström et al., 2009a). Thus defined, the PBs delimit a safe operating space for global Earth System processes within which humanity may operate without risking destabilisation of the Holocene state (Rockström et al., 2009a).

The building sector has a strong influence on total natural resource consumption and on release of emissions and waste to the environment. Currently, the construction industry accounts for $36 \%$ of European $\mathrm{CO}_{2}$ emissions and $40 \%$ of the total European energy 
consumption (European Commission, 2019). In Denmark alone the building industry produces 4.1 million tonne waste annually, or equal to a third of all waste produced in Denmark (DK-GBC, 2018). Hence, this sector is crucial to address in order for humans to stay within the safe operating space. A first step is to facilitate assessments of the building sector and environmental strategies in the building sector in relation to the environmental boundaries. Life cycle assessment (LCA) methods are commonly used for environmental assessment of activities in the building sector (Brejnrod et al., 2017) to support decision making, and for evaluating and optimising construction processes (Cabeza et al., 2014). LCA is a relative, environmental assessment method and is most often used in comparative assessments, i.e. to claim environmental superiority of one product over another, or in hotspot analysis' to identify the main environmental impacts of a product's life cycle (Hauschild et al., 2018; European Standard, 2008).

To use LCA for analysis of whether Earth System processes are able to cope with the burdens of human activities, it is necessary to couple LCA with absolute measures (Bjørn et al., 2015). The results are referred to as Absolute Environmental Sustainability Assessments (AESAs). AESAs allows assessing whether an activity can be considered sustainable relative to an absolute environmental sustainability reference (AESR). The AESR is defined by first identifying one or more relevant environmental boundaries, quantifying the safe operating space within each boundary and then assigning a share of it to the assessed activity. Second, the environmental impact of the activity is quantified using e.g. LCA. If the environmental impact of the activity is smaller than the share of the boundary assigned to the activity, then the activity can be considered environmentally sustainable in absolute terms (Ryberg et al., 2018a).

So far, two approaches have been used for defining AESRs, i.e. the environmental carrying capacity and the Planetary Boundaries of the Earth System. The Planetary Boundaries are based on the PBs as defined in e.g. Steffen et al. (2015b) and have been used as AESRs in e.g. Ryberg et al. (2018a) where impacts from the assessed activity were quantified in the metrics of the PBs via a PB based life-cycle impact assessment (PB-LCIA) methodology (Ryberg et al., 2018c). The environmental carrying capacity approach is e.g. based on Bjørn and Hauschild (2015) who derived carrying capacity based normalization references for existing LCIA methods used in LCA for quantifying and expressing environmental impacts. Further details on absolute environmental sustainability assessments can be found in 
Supporting Information I, Section II.I. Due to underlying differences in the LCIA methods and differences in the level of precaution used for setting AESRs, it is expected that conclusions about absolute sustainability will differ among AESAs depending on whether PBs or carrying capacity approaches are used.

The present study has two objectives, (i) to evaluate the robustness of conclusions based on AESAs depending on whether PBs or carrying capacity approaches are used and (ii) to evaluate to which degree different design approaches to single-family stand-alone dwellings can be considered absolute sustainable. To do so, two AESA approaches (i.e. carrying capacity-based normalisation factors ( $\mathrm{CC}_{\text {norm; }}$ Bjørn and Hauschild, 2015) and the PB-LCIA (Ryberg et al., 2018a, 2018c)) are applied and compared on a case study with six singlefamily stand-alone dwellings, that are built on the basis of different principles for being sustainable, climate wise.

\section{MATERIALS AND METHODS}

\subsection{Absolute Environmental Sustainability Assessment approaches}

To assess the importance of the choice of AESA approach we applied two novel approaches for absolute environmental sustainability assessment i.e. carrying capacity-based normalisation factors ( $\mathrm{CC}_{\text {norm}}$; Bjørn and Hauschild, 2015) and the PB-LCIA method (Ryberg et al., 2018a, 2018c).

It should be noted that the objective was only to test the robustness of the AESA conclusions to this choice of method. Hence, the objective was not to compare results obtained from the two methods, as they are inherently not comparable (in some cases they do not consider the same impact categories and when they do, the results are often calculated using different models and expressed in different units).

The work by Bjørn and Hauschild (2015) address the fact that "as common normalisation factors are solely based on activities within the technosphere they cannot be used to compare and aggregate the severity of different types of interventions in the ecosphere". This motivated the development of European and global carrying capacity-based normalisation factors compatible with characterised indicator scores at midpoint-level for impact categories that link to the Area of Protection "Natural Environment" (Bjørn and Hauschild, 2015). However, as the normalisation factors are not fully compliant with those of ILCD 2011 
Midpoint+ LCIA method (ILCD 2011), European Commission's Joint Research Centre (Sala et al., 2016) translated the normalisation references to be compliant with the ILCD 2011 impact categories to facilitate a wider used of the method. Bjørn and Hauschild (2015) define carrying capacity as "the maximum sustained environmental intervention a natural system can withstand without experiencing negative changes in structure or functioning that are difficult or impossible to revert”. In contrast to the PB-framework, which applies a precautionary approach, the carrying capacities in Bjørn and Hauschild (2015) are defined as a best estimate of the exact carrying capacity. This is done to avoid introducing a bias during normalization of different impact categories in LCA (Bjørn and Hauschild, 2015). Thus, in cases where the carrying capacity is expressed as an uncertain interval, the carrying capacity was defined as either the average or median value (Bjørn and Hauschild, 2015). This is indicated in Figure 1 where the carrying capacity is placed in the middle of the zone of uncertainty.

More recently, Ryberg et al. (2018c) developed an LCIA-method for characterizing the resource uses and emissions associated with an activity (collectively termed elementary flows) in the metrics of the PBs as defined in Steffen et al. (2015b). In contrast to conventional LCA and in order to express impacts in the metrics of the PBs, the elementary flows must be modelled and expressed as annual resource uses and emissions (Ryberg et al., 2018c). To do so, the functional unit must be defined as the annual provision of a function and the LCI must be modelled to express the annual "average" elementary flows associated with continuous annual fulfilment of the functional unit (Ryberg et al., 2018c). The ability to express the impacts of an activity in the metrics of the PBs allows for using the PBs as absolute environmental boundaries. 


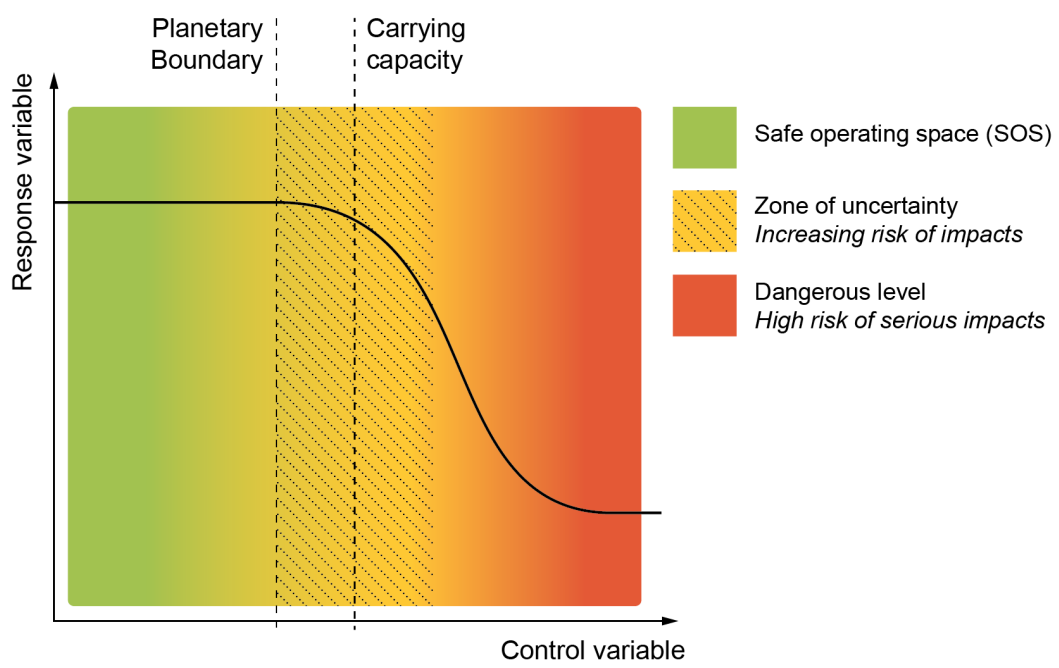

Figure 1 - The concept of Planetary Boundaries and carrying capacity framework for global Earth System processes. The green zone marks the safe operating space, the yellow zone the uncertainty and the red zone a high risk of critical change. The lines mark the Planetary Boundary (Rockström et al., 2009b) located at the lower limit of the zone of uncertainty and the carrying capacity located as an average in the zone of uncertainty as defined by Bjørn and Hauschild (2015)

\subsection{Allocating the safe operating space}

To assess if an activity can be considered absolutely sustainable it is necessary to assign a share of the total safe operating space within the environmental boundary to the activity. If the activity exceeds its assigned share of the space, then it cannot be considered absolutely sustainable as it contributes to an overall exceedance of the total environmental boundary. For the PBs, it should be noted that to be absolutely sustainable, all impacts should be within the assigned share of the safe operating space (SoSOS) for all impact categories. This is required as the transgression of one Earth System process might push other Earth System processes towards exceeding their threshold (Steffen et al., 2015b).

For some Earth System processes, the safe operating space also includes the space that is naturally occupied by the environment. Thus, the safe operating space that is to be shared among humans is determined by deducting the natural background levels for the relevant PBs (Ryberg et al., 2018a). The full safe operating space to be shared among humans (i.e. the 
Planetary Boundary or carrying capacity when the natural background level is subtracted) can be found in Supporting Information I, Section II.II and II.III.

The objects of analysis in this paper are all single-family stand-alone dwellings and it was therefore necessary to determine the share of the safe operating space that should be assigned to a building of this type. The assignment of a share of safe operating space (SoSOS) to an activity can be based on different principles of distribution, such as maximising the utility of the global population (i.e. utilitarianism), seeking equality among all people (i.e. egalitarianism), or distributing relative to current contribution to environmental impact (i.e. based on acquired rights) (Ryberg et al., 2018b).

For this study we will apply different sharing principles as a way of testing the robustness of our assessment, as Ryberg et al. (2018a) found that the choice of sharing principle has large influence on the assigned SoSOS and, thus, conclusions about absolute sustainability. We determined six combinations of sharing principles by utilising both egalitarian, utilitarian and acquired rights-based approaches (see Table 1). It should be noted that the sharing principles applied in this study only represent a selection of ways the safe operating space can be shared, for further literature on the topic, see Lucas et al. (2020), Sandin et al (2015), Ryberg et al. (2016), Bjørn et al. (2018), Häyhä et al. (2016), Vanderheiden, (2009). 
Table 1 - Sharing principles applied in this study.

\begin{tabular}{|c|c|c|c|}
\hline & $\begin{array}{l}\text { Person share out of } \\
\text { world share }\end{array}$ & $\begin{array}{l}\text { Household share out } \\
\text { of person share }\end{array}$ & $\begin{array}{l}\text { Dwelling share out } \\
\text { of household share }\end{array}$ \\
\hline $\begin{array}{l}\text { Sharing principle } 1 \\
\text { (egalitarian }+ \text { utilitarian) }\end{array}$ & $\begin{array}{l}\text { Equal per capita } \\
\qquad \frac{1}{\text { world }_{\text {pop }}}\end{array}$ & $\begin{array}{l}\text { Final consumption } \\
\text { expenditure } \\
\frac{\mathrm{FCE} E_{\mathrm{HH}}}{\mathrm{FCE}_{\text {person }}} \cdot N\end{array}$ & $\begin{array}{l}\text { Final consumption } \\
\text { expenditure } \\
\qquad \frac{\mathrm{FCE}_{\mathrm{dwe}}}{\mathrm{FCE}_{\mathrm{HH}}}\end{array}$ \\
\hline $\begin{array}{l}\text { Sharing principle } 2 \\
\text { (egalitarian }+ \text { utilitarian) }\end{array}$ & $\begin{array}{l}\text { Equal per capita } \\
\qquad \frac{1}{\text { world }_{\text {pop }}}\end{array}$ & $\begin{array}{l}\text { Time spent } \\
\frac{\mathrm{H}_{\text {home }}}{\mathrm{H}_{\text {year }}} \cdot N\end{array}$ & $\begin{array}{l}\text { Final consumption } \\
\text { expenditure } \\
\qquad \frac{\mathrm{FCE}_{\mathrm{dwe}}}{\mathrm{FCE}_{\mathrm{HH}}}\end{array}$ \\
\hline $\begin{array}{l}\text { Sharing principle } 3 \\
\text { (egalitarian }+ \text { acquired rights) }\end{array}$ & $\begin{array}{l}\text { Equal per capita } \\
\qquad \frac{1}{\text { world }_{\text {pop }}}\end{array}$ & $\begin{array}{l}\text { Energy consumption } \\
\qquad \frac{\mathrm{E}_{\mathrm{HH}}}{\mathrm{E}_{\text {person }}} \cdot N\end{array}$ & $\begin{array}{l}\text { Energy consumption } \\
\qquad \frac{\mathrm{E}_{\mathrm{dwe}}}{\mathrm{E}_{\mathrm{HH}}}\end{array}$ \\
\hline & Household share & ut of world share & $\begin{array}{l}\text { Dwelling share out } \\
\text { of household share }\end{array}$ \\
\hline $\begin{array}{l}\text { Sharing principle } 4 \\
\text { (acquired rights }+ \text { acquired } \\
\text { rights) }\end{array}$ & $\begin{array}{r}\mathrm{CO}_{2} \mathrm{e} \\
\mathrm{CC} \\
\mathrm{CO}\end{array}$ & $\begin{array}{l}\text { ssions } \\
\mathrm{H} \\
\mathrm{rld}\end{array}$ & $\begin{array}{l}\text { Energy consumption } \\
\qquad \frac{\mathrm{E}_{\mathrm{dwe}}}{\mathrm{E}_{\mathrm{HH}}}\end{array}$ \\
\hline $\begin{array}{l}\text { Sharing principle } 5 \\
\text { (acquired rights }+ \text { utilitarian) }\end{array}$ & $\mathrm{CO}_{2} \mathrm{e}$ & ssions & $\begin{array}{l}\text { Final consumption } \\
\text { expenditure } \\
\qquad \frac{\mathrm{FCE}_{\mathrm{dwe}}}{\mathrm{FCE}_{\mathrm{HH}}}\end{array}$ \\
\hline & \multicolumn{3}{|c|}{ Dwelling share out of world share } \\
\hline $\begin{array}{l}\text { Sharing principle } 6 \\
\text { (utilitarian) }\end{array}$ & & $\begin{array}{l}1 \text { consumption expendit } \\
\frac{\mathrm{CE}_{\text {dwe }}}{\mathrm{CE}_{\text {world }}}=\frac{\mathrm{FCE}_{\mathrm{HH}}}{\mathrm{FCE}_{\mathrm{worl}}} \cdot \frac{\mathrm{FCE} \mathrm{E}_{\mathrm{dwe}}}{\mathrm{FCE}_{\mathrm{HH}}}\end{array}$ & \\
\hline
\end{tabular}

Table 1 includes the following elements: Pop world is the world population, $\mathrm{FCE}_{\mathrm{HH}}$ is the final consumption expenditure for a household, $\mathrm{FCE}_{\text {person }}$ is the final consumption expenditure for a person, $\mathrm{FCE}_{\mathrm{dwe}}$ is the final consumption expenditure for a dwelling, $\mathrm{N}$ is the number of persons in a household, $\mathrm{H}_{\text {home }}$ is the hours spent at home, $\mathrm{H}_{\text {year }}$ is the hours in a year, $\mathrm{E}_{\mathrm{HH}}$ is the energy consumption for an average household, $\mathrm{E}_{\text {person }}$ is the energy consumption for one 
person, $\mathrm{E}_{\mathrm{dwe}}$ is the energy consumption for a dwelling, $\mathrm{CO} 2 \mathrm{HH}$ is the $\mathrm{CO}_{2}$ emitted for an average household and $\mathrm{CO} 2$ world is the $\mathrm{CO}_{2}$ emitted worldwide. All factors are considered on an annual basis. This study distinguishes between a household and dwelling. A person's household includes all home-based activities and products, e.g. cooking, cleaning, furniture etc., while $d$ welling refers to activities and products linked to the building itself, i.e. floorings, major appliances etc. The share assigned to a single-family stand-alone dwelling, is calculated by multiplying the fractions across each row. The calculated shares can be found in Supporting Information I, Section III.III. Further details on how the shares were calculated can be found in Supporting Information I, Section II.IV.

To determine if the studied dwellings can be considered absolutely sustainable we calculate the share that each dwelling occupies of the SoSOS, by applying the sharing principle to the full safe operating space of either the PB or carrying capacity as shown in Equation 1 and 2:

$$
\text { (1) } \frac{C_{I S}^{P B-L C I A}}{S P_{i} \cdot \operatorname{SOS}_{P B, i}}=\frac{C_{I S}^{P B-L C I A}}{\operatorname{SoSOS}_{i}} \leq 1 \quad \text { (2) } \frac{C_{I S}}{S_{i} \cdot \operatorname{SOS}_{C C, \text { world }, i}}=\frac{C_{I S}}{\operatorname{SoSOS}_{i}} \leq 1
$$

$\mathrm{C}_{\mathrm{IS}}{ }^{\mathrm{PB}-\mathrm{LCIA}}$ is a characterised impact potential calculated with PB-LCIA, and SOS ${ }_{\mathrm{PB}, \mathrm{i}}$ is the full safe operating space of the PBs for impact category $i$ (see Supporting Information I, Section II.II). $\mathrm{C}_{\text {IS }}$ is the characterised impact potential calculated using ILCD 2011 divided by

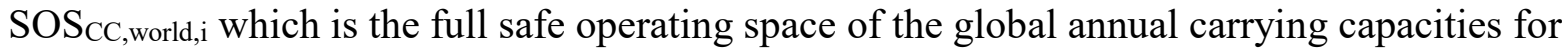
impact category $i$. SOS $\mathrm{CC}_{\mathrm{C} \text {,world, } \mathrm{i}}$ is represented by the carrying capacity-based normalisation references (see Supporting Information I, Section II.III) (Brejnrod et al., 2017). $\mathrm{SP}_{\mathrm{i}}$ is the sharing principles presented in Table 1. SoSOS $_{\mathrm{i}}$ represents the share of safe operating space of impact category $i$ assigned to a single-family stand-alone dwelling of the total safe operating space. If the share is $\leq 1$, a dwelling can be considered within its assigned SoSOS and, thus, absolutely sustainable.

\subsection{Case study}

In this study we investigated five dwellings known as the MiniCO2 Houses (for more details on the project see Supporting Information I, Section II.V) and compared these to a sixth house (referred to as the Reference House (Ref House)), which reflects standard Danish building practice in 2015 and serves as a benchmark in this study. The MiniCO2 Houses were designed to each reduce one known source of $\mathrm{CO}_{2}$ emissions in buildings to an extreme 
degree, i.e. one design parameter is highlighted and optimised while all other parameters are designed to simply comply with (at that point of time) current building regulations, enabling a comparison between the different parameters and showing the impact of different actions towards $\mathrm{CO}_{2}$ reductions.

The first, Upcycle House (UP House), focuses on how use of recycled building materials and materials with a high recycling content can save resources and decrease $\mathrm{CO}_{2}$ emissions during construction of buildings. The Innovative Maintenance-free House (IMF House) and the Traditional Maintenance-free House (TMF House) excel in two areas; maintenance and service life. The two dwellings differ by the choice of materials. TMF House is built from traditional materials that are known to have a long service life, while IMF House is built from new materials that are expected to have a long service life. Both dwellings have a theoretical service life of 150 years and a building envelope that does not require any maintenance during the first 50 years of use. The concept of the Adaptable House (AD House) is flexibility and variability during its service life. The house is built of components that can be disassembled, providing the opportunity to expand the house without destroying existing and remaining components. The final house, Quota House ( $Q$ House) focuses on smart technology, the behaviour of the residents and their consumption patterns (Rasmussen et al., 2019; Realdania Byg and Kleis, 2014a, 2014b, 2013a, 2013b; Realdania Byg and Leth \& Gori, 2014).

Table 2 - Characteristics of the MiniCO2 Houses

\begin{tabular}{ll} 
Dwelling & Characteristic \\
\hline Upcycle House & $\begin{array}{l}\text { Recycled building materials and materials } \\
\text { with a high recycling content }\end{array}$ \\
The Innovative Maintenance-free House & $\begin{array}{l}\text { New, innovative materials with low } \\
\text { maintenance providing a long service life }\end{array}$ \\
The Traditional Maintenance-free House & $\begin{array}{l}\text { Traditional materials with low maintenance } \\
\text { providing a long service life }\end{array}$ \\
The Adaptable House & $\begin{array}{l}\text { Flexibility in building components making } \\
\text { it possible to expand }\end{array}$ \\
The Quota House & $\begin{array}{l}\text { Smart technology to affect the behaviour of } \\
\text { the residents to reduce energy consumption }\end{array}$
\end{tabular}

All modelled systems contain parameters that are likely to change in the future, e.g. energy consumption, disposal routes, and energy mix. We identified five key characteristics of the 
buildings which current trends point towards as likely development paths in the coming years based on a study by SPREAD Sustainable Lifestyles (Backhaus et al., 2011). Therefore, we defined five scenarios each representing a version of the future where one parameter is highlighted. In Table 3 the modelled modifications are presented. We modelled the change in each characteristic as an improvement in environmental performance, i.e. contributing to a lower environmental impact than the current conditions (Base Scenario), thereby representing a more sustainable version of the future. Finally, we defined a sixth scenario where all characteristics are changed and thus represents a best case scenario. It should be noted that the characteristics from Scenario 1 to 5 are mutually complementary and can be combined without conflicting assumptions. An extensive description of the scenarios can be found in Supporting Information I, Section II.VI.

Table 3 - An outline of the scenarios assessed in this study are presented.

\begin{tabular}{|c|c|c|}
\hline & Characteristic modified & How? \\
\hline \multirow[t]{13}{*}{ Base Scenario } & Current conditions & AD House is expanded 3 times, whereas the \\
\hline & & remaining houses are expanded 1 time - (see \\
\hline & & Supporting Information 1, Section II.VII.II) \\
\hline & & Energy heat use is $3528 \mathrm{kWh}$ for Q House and 4278 \\
\hline & & $\mathrm{kWh}$ for the remaining houses \\
\hline & & Energy electricity use for ventilation is $2.1 \mathrm{kWh} / \mathrm{m}^{2}$ \\
\hline & & for all houses \\
\hline & & Energy mix is modelled as for 2018 (average grid \\
\hline & & mix) \\
\hline & & Estimations of service life of materials and End of \\
\hline & & Life routes are according to current conditions (see \\
\hline & & Supporting Information 1, Section IV for \\
\hline & & specifications) \\
\hline \multirow[t]{2}{*}{ Scenario 1} & Expansion & Buildings are modelled without expansion, i.e. \\
\hline & & building area is decreased \\
\hline Scenario 2 & Energy consumption & Energy use is reduced with $25 \%$ \\
\hline \multirow[t]{2}{*}{ Scenario 3} & Energy mix & Energy mix is modelled as projected for 2030 \\
\hline & & (average grid mix) \\
\hline Scenario 4 & Service life of materials & Service lives of all materials are doubled \\
\hline
\end{tabular}




\subsection{Life Cycle Assessment}

LCA is a standardized method described in ISO 14040:2008 and ISO 14044:2008 (European Standard, 2008) and specifically for construction in EN 15978:2011 (CEN, 2011). In the following subsections a description of aspects relevant to the modelling process of the six dwellings is given.

\subsubsection{Scope definition}

In typical LCAs, defining the functional unit (FU) includes defining for how long the function is provided (Hauschild et al., 2018). In this case, how long would be the service life of the building (120 years for Ref, UP, AD and Q House or 150 years for TMF and IMF House). However, to reflect the framework described in Section 2.1 the inventory must express elementary flows as continuous constant input per unit of time rather than an input integrated over time and thus the inventory is scaled to an annual basis in respect to the corresponding service lives (either 120 or 150 years) (Ryberg et al., 2018c). The FU of the compared systems was defined as to annually house one family in a stand-alone dwelling in Denmark. The life cycle inventory (LCI) data used to model the foreground system are representative for a Danish context, and all parameters e.g. energy mix were modelled according to current conditions in Denmark. All systems were modelled using the software tool SimaPro 8.0 (PRé, 2019) with the database Ecoinvent 3.4 (Ecoinvent, 2019). The system boundaries are presented in Figure 2. Further details regarding scope definition can be found in Supporting Information I, Section II.VII.I. 


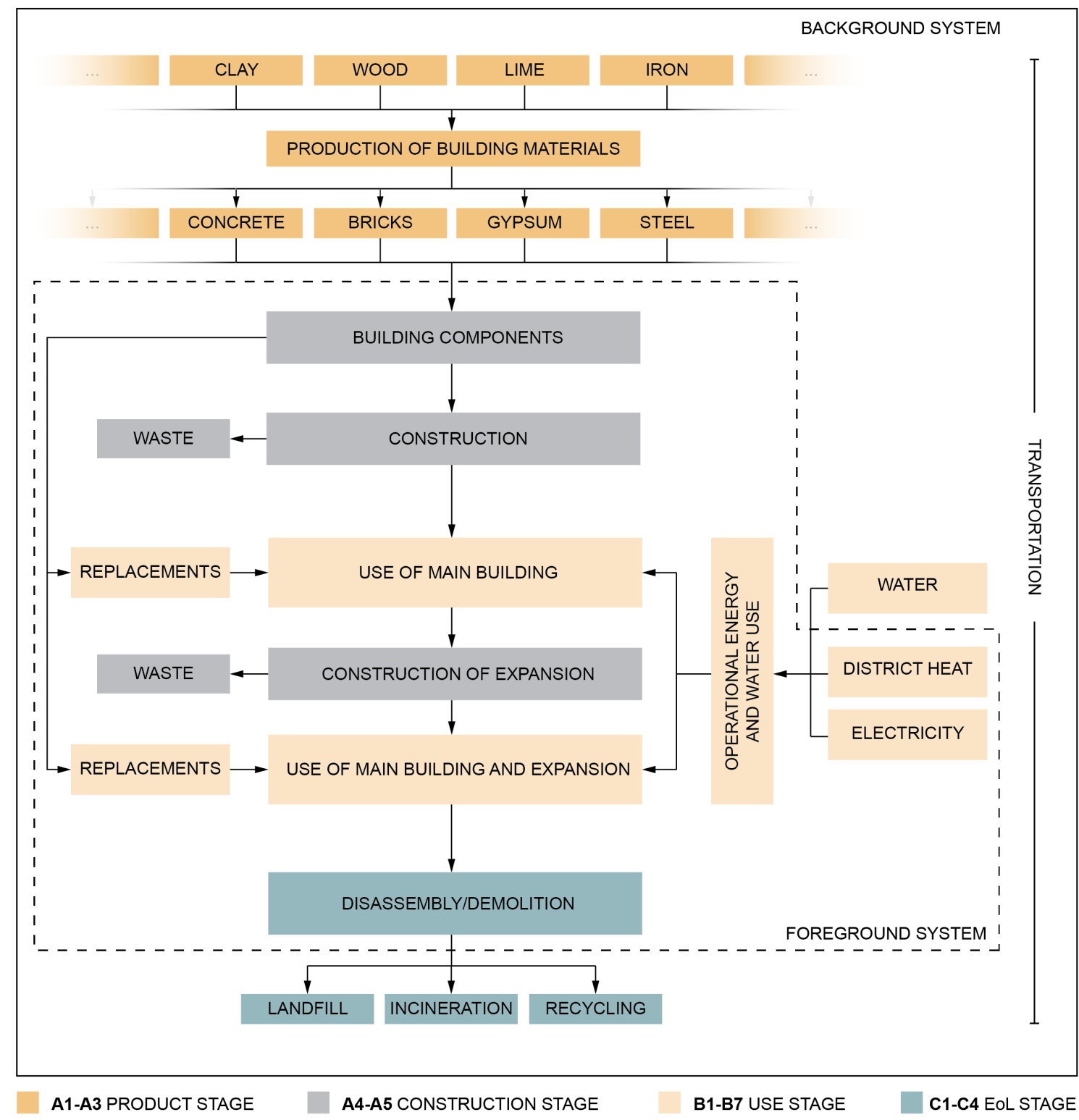

Figure 2 - System boundaries for all modelled systems.

\subsubsection{Life Cycle Inventory}

The data used to model the inventory were supplied by the design teams of each building and all inventories can be seen in Supporting Information II. The provided data only cover building components, and all inventory data regarding Construction, Use, and End of Life were therefore based on either Environmental Product Declarations (EPDs), relevant literature, or assumptions. A full list of all assumptions regarding the inventories can be found in Supporting Information I, Section IV.

The uncertainty induced by the inventories was assessed quantitatively via Monte Carlo analysis. Uncertainties regarding assumptions were considered qualitatively. In addition, the 
sensitivity of the Base Scenario model was tested towards the changes made in Scenario 1-6. The relative change was calculated and used as a measure of sensitivity in the model. It was assumed that if the relative change is greater than $2 \%$ the model can be considered sensitive. Furthermore, a normalised sensitivity coefficient (Owsianiak et al., 2018) was calculated for a $10 \%$ change in district heating consumption, energy for construction and the service life of the buildings (for further details, see Supporting Information I, Section II.VII.II). The normalised sensitivity coefficient represents the relative change in impact divided by the relative change in input and it was assumed that if the normalised sensitivity coefficient is greater than 0.5 for a single impact category, the parameter is considered sensitive. Similarly, a parameter was seen as sensitive if the average of the sensitivity coefficients for all impact categories is greater than 0.3 (Cohen et al., 2014; Ryberg et al., 2015). Further details can be found in Supporting Information I, Section II.VII.II.

\subsubsection{Life Cycle Impact Assessment (LCIA)}

Two different impact assessment methods were applied in this study. These are described in Section 2.1. Maslesa et al. (2018) carried out a literature review in which they investigate which impact categories are used in 25 LCA studies within the building sector in Europe and the USA over the past 15 years. They found that the most commonly used impacts were related to climate change, acidification, eutrophication and ozone depletion. Based on this we decided to include the impact categories Climate change ( $\mathrm{kg} \mathrm{CO}_{2} \mathrm{eq}$ ) and Marine eutrophication ( $\mathrm{kg} \mathrm{Neq}$ ) from the LCIA-method ILCD 2011 and Climate change - energy imbalance $\left(\mathrm{Wm}^{-2}\right)$ and Biogeochemical flows $-N(\operatorname{Tg} N)$ from the Planetary Boundary based LCIA-method (Ryberg et al., 2018). Furthermore, we decided to include impacts related to land use and water use, as we expected both to be relevant in a building context. Therefore, we included the impact categories Land use ( $\mathrm{kg} C$ deficit) and Water resource depletion $\left(\mathrm{m}^{3}\right.$ water eq) from the LCIA-method ILCD 2011 and Land system change-global (\%) and Freshwater use - global $\left(\mathrm{km}^{3}\right)$ from the Planetary Boundary based LCIA-method. The impact categories related to nitrogen were included as they represent an important contributor to anthropogenic pressures that can have serious consequences for Earth System processes functioning (Desmit et al., 2018). The considered impact categories is presented in Table 4. Further details regarding choice of impact coverage can be found in Supporting Information I, Section II.VII.III.

Table 4 - The impact categories considered in this study for the two methods respectively 


\begin{tabular}{ll}
\hline Impact categories $\mathbf{C C}_{\text {norm }}$ & Impact categories PB-LCIA \\
\hline Climate change $(\mathrm{kg} \mathrm{CO} \mathrm{eq})$ & Climate change - energy imbalance $\left(\mathrm{Wm}^{-2}\right)$ \\
Marine eutrophication $(\mathrm{kg} \mathrm{N}$ eq $)$ & Biogeochemical flows $-\mathrm{N}(\mathrm{Tg} \mathrm{N})$ \\
Land use ( $\mathrm{kg} \mathrm{C}$ deficit) & Land system change - global $(\%)$ \\
Water resource depletion $\left(\mathrm{m}^{3}\right.$ water eq) & Freshwater use - global $\left(\mathrm{km}^{3}\right)$ \\
\hline
\end{tabular}

\section{RESULTS}

In order to make the results transparent and comparable to similar building studies, the characterised results obtained using ILCD 2011 are presented in Table 5. The lowest impact potential is marked in green, the highest in red. 
Table 5 - Characterised annual impact potential for each of the MiniCO2 Houses for the Base Scenario using the LCIA method ILCD 2011.

\begin{tabular}{|c|c|c|c|c|c|c|}
\hline Impact category & $\operatorname{Ref}^{a}$ & $\mathbf{U P}^{\mathbf{a}}$ & $\mathbf{T M F}^{\mathbf{b}}$ & $\mathbf{I M F}^{\mathbf{b}}$ & $\mathbf{A} \mathbf{D}^{\mathbf{a}}$ & $\mathbf{Q}^{\mathbf{a}}$ \\
\hline Climate change $\left[\mathrm{kg} \mathrm{CO} \mathrm{C}_{2}\right.$ eq] & $1.30 \times 10^{3}$ & $1.33 \times 10^{3}$ & $1.20 \times 10^{3}$ & $1.05 \times 10^{3}$ & $1.62 \times 10^{3}$ & $1.14 \times 10^{3}$ \\
\hline Marine eutrophication [ $\mathrm{kg} \mathrm{N}$ eq] & 1.56 & 1.47 & 1.52 & 1.97 & 2.01 & 1.56 \\
\hline Land use [kg C deficit] & $6.33 \times 10^{3}$ & $7.27 \times 10^{3}$ & $7.03 \times 10^{3}$ & $1.04 \times 10^{4}$ & $1.96 \times 10^{4}$ & $6.74 \times 10^{3}$ \\
\hline $\begin{array}{l}\text { Water resource depletion } \\
{\left[\mathrm{m}^{3} \text { water eq] }\right.}\end{array}$ & 9.54 & 9.84 & 9.80 & 9.93 & $1.39 \times 10^{1}$ & 8.49 \\
\hline \multicolumn{7}{|l|}{${ }^{2} 120$ year service life } \\
\hline \multicolumn{7}{|l|}{${ }^{b} 150$ year service life } \\
\hline
\end{tabular}

The results presented in Table 5 shows that AD House has the highest environmental impact potential in 3 out of 4 of the considered impact categories, whereas the house with the lowest environment impact potential varies between the impact categories. The larger environmental impact potential in AD House is due to additional material consumption when expanding the house 3.03 times during the service life. Indeed, a contribution analysis showed that the choice and amount of materials used over the house's service life has a large influence on the environmental performance. Moreover, the contribution analysis showed that the Use stage was found to be the main contributor to the environmental impact potential across all impact categories due to consumption of electricity and district heating (see Supporting Information I, Section III.II for further details and results from the contribution analysis).

The impact potentials relative to the assigned SoSOS for the six dwellings, the two scenarios and the method $\mathrm{CC}_{\text {norm }}$ are presented in Figure 3. The figure shows the extent to which each house exceeds the assigned SoSOS when considering the six different sharing principles and the LCI uncertainty. The red line in the Figure indicates the boundary and assigned SoSOS, which means that if the impact potential is above the line, hence above 1 , the boundary is exceeded. The error bars indicate the LCI uncertainty in combination with the ranges across the applied sharing principles, where the latter dominate the uncertainty. In the figure, the results are shown on a logarithmic scale. Consequently, for the impact category Water resource depletion the uncertainty range is only expressed from the mean to the upper limit of 
the confidence interval $(97.5 \%)$ as the lower limit $(2.5 \%)$ reaches a negative value, which cannot be presented on a logarithmic scale.

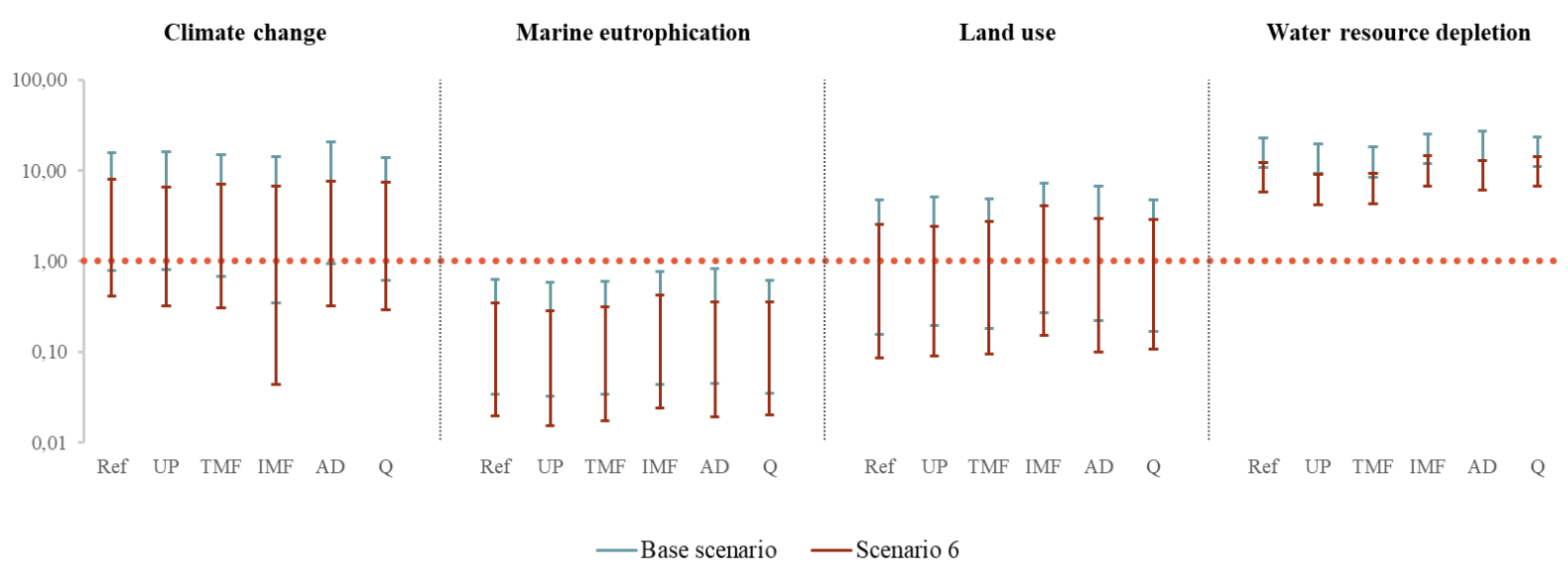

Figure 3 - Impact potential relative to the assigned SoSOS for the Base Scenario and Scenario 6 for each of the five MiniCO2 houses for four impact categories and applying the method $C C_{n o r m}$. The bar for each house represents the variation across six different sharing principles.

Ref - Reference House, UP - Upcycle House, TMF - Traditional Maintenance-free House, IMF - Innovative Maintenance-free House, AD - Adaptable House, Q - Quota House

The results obtained for the Base Scenario using the method $\mathrm{CC}_{\text {norm }}$ show that the MiniCO2 Houses are within the assigned SoSOS in 1 out of 4 impact categories, but that the dwellings with varying certainty exceed the assigned share in the rest of the impact categories considered in this study (see Figure 3 and Supporting Information I, Section III). In general, we find that AD House has the highest impact potential in 3 out of 4 impact categories for the Base scenario and thus is one of the worst performing MiniCO2 Houses. For Climate change, AD House exceeds the assigned SoSOS by on average a factor 6.6 across sharing principles, whereas IMF House, with the lowest impact potential for Climate change, exceeds the assigned SoSOS by an average of a factor 4.3 across sharing principles (see Supporting Information I, Section III). However, considering the remaining impact categories the results show that UP House and Q House are among the best performing dwellings, where UP House excels in the impact categories Marine eutrophication and Land use and Q House in Water resource depletion and Climate change. The results obtained for Scenario 6 using the method $\mathrm{CC}_{\text {norm }}$ support the same conclusion as the results obtained for the Base Scenario, namely that the impact potential of the MiniCO2 Houses exceeds the assigned SoSOS in 3 out of 4 impact 
categories (see Figure 3 and Supporting Information I, Section III). However, the results show that the improvements included in Scenario 6 bring the impact potential of dwellings closer to stay within the assigned SoSOS. For the impact category Climate change, Ref House is found to be the dwelling with the highest impact potential exceeding the assigned share by averagely a factor 2.7 across sharing principles. For the same impact category, IMF House is found to have the lowest impact potential and thus is the dwelling that comes closest to staying within the assigned SoSOS by an average of a factor 1.7 across sharing principles. However, for the impact categories Land use and Marine eutrophication IMF House is among the worst performing dwellings, whereas UP House is the best performing dwelling being within the assigned SoSOS for both impact categories. Finally, for the impact category Water resource depletion, Q House is the MiniCO2 House with the lowest environmental impact, on average occupying only 0.17 of the assigned SoSOS.

The environmental performance of the MiniCO2 Houses thus depends on which impact category is considered. For the impact category Marine eutrophication, Figure 3 shows that the MiniCO2 Houses are all likely to stay within the assigned SoSOS for all sharing principles, whereas for the impact categories Land use and Water resource depletion, the sharing principle and LCI uncertainty determines whether the dwellings are within the assigned SoSOS. However, in order for the dwellings to be considered absolutely sustainable, the environmental impact of the dwellings must be within the assigned SoSOS for all impact categories.

The similar results, obtained using the PB-LCIA method, are presented in Figure 4 and in Supporting Information I, Section III. 


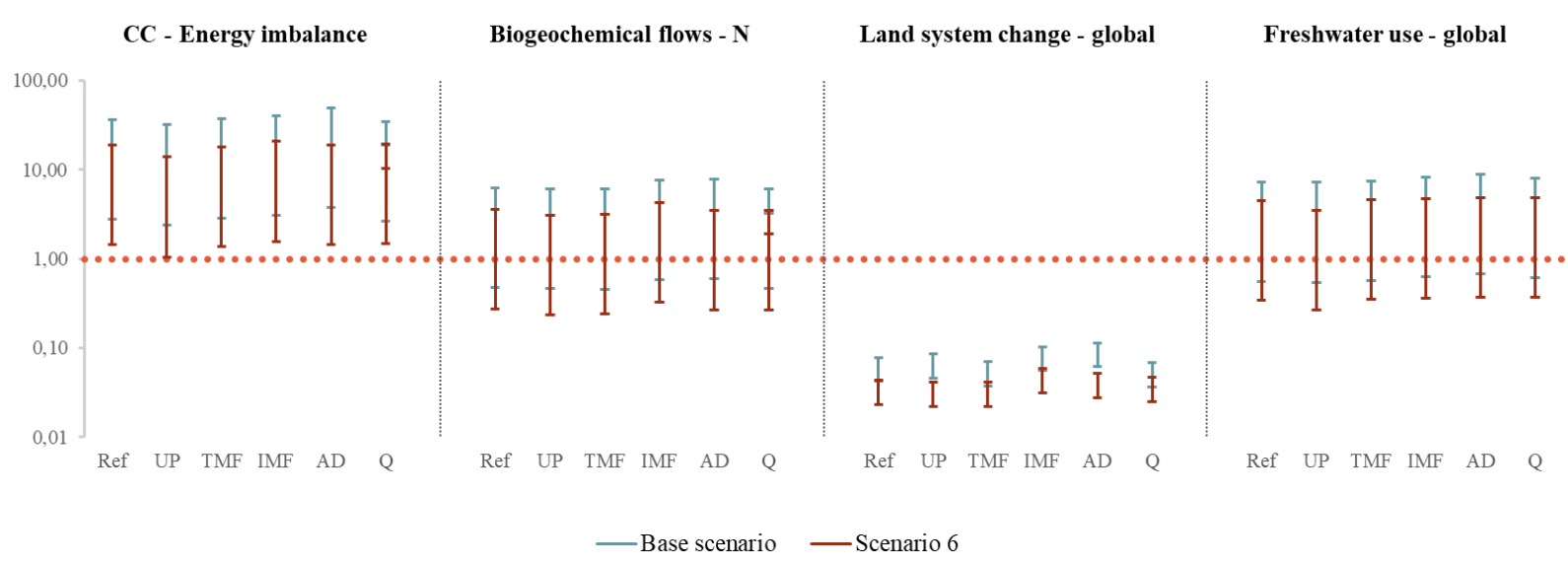

Figure 4 - Impact potential relative to the assigned SoSOS for the Base Scenario and

Scenario 6 for each of the five MiniCO2 houses for four impact categories and applying the PB-LCIA method. The bar for each house represents the variation across six different sharing principles.

Ref-Reference House, UP - Upcycle House, TMF - Traditional Maintenance-free House, IMF - Innovative Maintenance-free House, AD - Adaptable House, Q - Quota House

The results presented in Figure 4 focusing on the Base Scenario using the PB-LCIA method show that the MiniCO2 Houses are within the assigned SoSOS in 1 out of 4 impact categories and that they most likely exceed the assigned SoSOS in 3 out of 4 impact categories (see Figure 4 and Supporting Information I, Section III), which corresponds to the results obtained using $\mathrm{CC}_{\mathrm{norm}}$. For Climate change - energy imbalance, AD House exceeds the assigned share of the PBs by an average of a factor 17.5 across sharing principles and is thus the worst performing dwelling in this impact category. For the same impact category, Climate changeenergy imbalance, the dwelling with the lowest impact potential is UP House and exceeds the boundaries by averagely a factor 11.3 across sharing principles. In general we find that UP House excels in the impact categories Climate change - energy imbalance, Land system change - global and Freshwater use - global, whereas TMF House excels in Biogeochemical flows $-N$. The results obtained for Scenario 6 show that the MiniCO2 houses are closer to staying within the assigned SoSOS than in the Base Scenario, however still far from reaching a definite absolutely sustainable level. IMF House is found to be the dwelling with the highest impact potential for the impact categories Climate change-energy imbalance, Biogeochemical flows $-N$ and Land system change - global, where Climate change - energy imbalance IMF House exceeds the assigned SoSOS by an average factor of 7.6 (see Supporting Information I, Section III). It is found that UP House is the house with the lowest 
impact potential irrespective of the impact category, but it still exceeds the assigned SoSOS by an average of a factor 4.9 for the impact category Climate change-energy imbalance (see

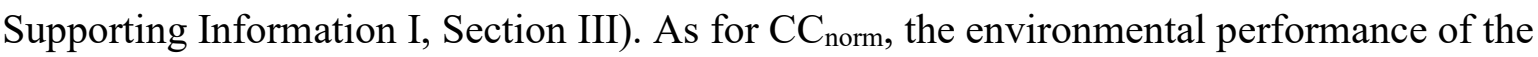
dwellings depends on the considered impact categories. For the impact category Land-system change - global, all dwellings stay within the assigned SoSOS irrespective of the LCI uncertainty and of the choice of sharing principle, however for the impact category Biogeochemical flows $-N$ and Freshwater use - global, the exceedance of the assigned SoSOS is dependent on the sharing principles and on the LCI uncertainty.

\section{DISCUSSION}

In the Base Scenario using the $\mathrm{CC}_{\text {norm}}$, Q House, Ref House and TMF House are absolutely sustainable if applying sharing principle 4 (acquired rights+acquired rights - see Table 1) and accounting for the uncertainties in the model. However, if applying one of the other five sharing principles, no house is within the assigned Table SoSOS. Applying PB-LCIA, no house is absolutely sustainable in the Base Scenario irrespective of which sharing principle is applied, indicating that even the best attempts at designing single-family stand-alone dwellings are insufficient. If considering the best case scenario, Scenario 6 , and $\mathrm{CC}_{\text {norm, all }}$ dwellings are absolutely sustainable when applying sharing principle 4. Contrarily, for PBLCIA only UP House is absolutely sustainable in Scenario 6 if applying sharing principle 4, thus calling for improvements in other dwellings.

The results obtained in this study indicate that the choice of architectural design of the dwellings within the five different designs may have little impact on the dwellings' ability to stay within the assigned SoSOS. From Section 3 it is evident that for the majority of the considered impact categories, the dwellings either all stay within the SoSOS or all exceed the assigned share. The exceedance of the SoSOS may be dominated by the energy consumption for building operation, which we assumed to be the same for all dwellings (except Q House), and thus differences caused by architectural design will appear minor. However, there is a clear tendency in the results that using recycled or reused materials in the product stage decreases the environmental impacts of a dwelling. This is supported by Table S13 in Supporting Information, which shows that the product stage's share of the total life cycle impacts for UP House is generally lower than for the other houses. Another advantage of UP House is its size $\left(129 \mathrm{~m}^{2}\right)$ as a smaller area will lead to less operational energy consumed. This could also be part of the reason why Q House performs well, as its area is only slightly 
larger $\left(138 \mathrm{~m}^{2}\right)$. These findings are in line with Brejnrod et al. (2017), who also identifies size as important for a house' environmental performance. As energy consumption appears an important factor (supported by the decrease in impacts from the Base Scenario to Scenario 2 and 3, where energy consumption is reduced and the energy grid mix contains a larger share of renewable energy sources, respectively) it is clear that action is needed to move from current conditions to these possible future scenarios. A reduction in energy consumption can be achieved by changes in our way of living, while the composition of the energy grid mix requires the attention of policy makers. Finally, the results indicate that the structural system of wood in IMF House and UP House has a positive effect in climate change-related impact categories when impact assessment is done with ILCD 2011.

\subsection{Influence of the sharing principles}

Table S23 and S31 in Supporting Information I, Section III.V shows the sizes of the shares assigned by each sharing principle. The difference between the sharing principle that assigns the smallest SoSOS (sharing principle 1) and the sharing principle that assigns the largest SoSOS (sharing principle 4) to a single-family stand-alone dwelling is approximately a factor 12, demonstrating the crucial influence of the sharing principle on how large a SoSOS is occupied by the dwellings. As sharing principle 4 (i.e. acquired rights based by considering $\mathrm{CO}_{2}$ emissions and energy consumption) assigns a larger SoSOS to the dwellings than the remaining sharing principles, more dwellings stay within the boundaries when this sharing principle is applied. This finding is in line with what has previously been established about the importance of the choice of sharing principle by both Sandin et al. (2015) and Ryberg et al. (2018). For the impact categories Climate change, Land use, Water resource depletion, Biogeochemical flows - N and Freshwater use - global, the choice of sharing principle determines whether a house is within the assigned SoSOS. The definition of six varying sharing principles is an attempt at highlighting the uncertainty linked to the choice of sharing principle, but also an approach to a question without an answer - i.e. who has the right to impact the environment how much? It is a question, which cannot be answered without an ever-present bias depending on who replies.

Sandin et al. (2015) considers the question a matter of ethics, and attempts to answer the question by applying four common ethical principles. As has previously been argued by Brejnrod et al. (2017) there is no objective way to assign the SOS to a building or any other service, as the sharing principle will always be seen as more or less fair depending on the 
eyes of the beholder. While equal per capita sharing of the safe operating space may seem fair given the implied equality of all individuals, it is not given that all people require the same size of "ecological resource" to experience an equal degree of welfare (Ryberg et al., 2018b). As, for instance, argued by Ryberg (2018), people living in colder regions may require a larger SoSOS relative to people living in warmer regions because they would need energy for heating to experience the same degree of wellbeing. On the other hand, when considering sharing principles based on acquired rights there will be bias placed towards existing activities which currently have a high contribution to impacts, while activities that have a low contribution to impacts are assigned a smaller share (Ryberg et al., 2018b).

\subsection{Choice of AESA approach}

An objective of this paper was to test the robustness of the results towards the choice of AESA approach. The results presented in Section 3 show that the two approaches lead to somewhat different conclusions on whether or not each MiniCO2 House can be considered absolutely sustainable now and in future scenarios. Overall, $\mathrm{CC}_{\text {norm }}$ finds more dwellings to be absolutely sustainable, some even in the Base Scenario if the LCI uncertainty is considered. Given the underlying theory of the two methods presented in Section 2.1, we expected that when applying the PB-LCIA methodology a (relatively) larger SoSOS would be occupied by the dwellings, as the Planetary Boundaries are defined as "below" the carrying capacity of our planet (see Figure 1). We suspected that this could be one cause for the pattern observed in the results obtained with the two methods.

Another supplementing cause could be the inherent differences of the $\mathrm{CC}_{\text {norm }}$ and PB-LCIA frameworks. In $\mathrm{CC}_{\text {norm }}$ carrying capacities are adapted as normalisation factors to comply with the impact categories of ILCD 2011, whereas in PB-LCIA characterisation factors are adapted to fit with the Planetary Boundaries. This means that the results are difficult to compare, as the impact categories are simply not directly comparable. Ryberg (2018) found that while Climate change - energy imbalance (PB-LCIA) has high coefficients of correlation with the impact category Climate change (ILCD 2011) and could thus potentially be considered comparable, others cannot be compared such as Land-system change - global (PB-LCIA) and Land use (ILCD 2011) due to low coefficients of correlation (Ryberg et al., 2018c). It should be noted that this is an aspect that has not been thoroughly investigated yet and possibly more work is required in this area. 


\subsection{Limitations and recommendations}

One of the most relevant limitations in the modelling of the studied systems is the service life of the MiniCO2 Houses. Assuming a realistic service life for building components as well as the entire building was one of the main challenges when the inventories were compiled. We decided to strive for consistency in the modelling and therefore based all assumptions on theoretical estimates of service life under Danish conditions (Aagaard et al., 2013). This parameter is not only related to a high level of uncertainty, it will be subject to a high degree of variability and thus have the potential to influence the results. As example, a longer service life allocates the impacts of construction and demolition to a higher number of years resulting in lower impact per functional unit. Based on this it should be considered if a different approach to predicting the service life of the building could be adopted. One possible alternative approach is a study by Østergaard et al. (2018), where the service life of buildings is determined by the choice of cladding materials, location and use type. Applying this approach would have meant modelling an individually estimated service life of each MiniCO2 House. This could potentially have made the modelled systems a more accurate representation of reality, but we decided to focus on consistency in the modelling approach and therefore chose to model the service life equal for all dwellings.

Another challenge in modelling the dwellings was deciding what to include in the use stage of the life cycle. As mentioned in Section 2.2 we distinguish between a household and dwelling, and assign a SoSOS to the dwelling, thereby leaving out all the activities taking place within the household, such as cooking, cleaning, and entertainment. However, this distinction challenges the fair comparison among the MiniCO2 Houses, as the main benefit of the Q House is in fact the lowered impacts from activities taking place within the household. Although less can be said about the actual environmental potential of the Q House, we decided to include the Q House as the scope of the study is an assessment of the building itself, not user behaviour. To express the potential benefits of the $\mathrm{Q}$ house, the scope must be expanded to cover user behaviour and consumption of products and services used in the household. This was outside the scope of this study, but would be relevant to further investigate, to obtain a more comprehensive assessment of the absolute environmental performance of the dwelling.

As described in previous sections it is clear that the choice of sharing principle has a determining effect on how much of the SoSOS is occupied. This is a challenge, as it is 
inherently a matter of ethics and therefore problematic to apply when an objective conclusion is strived for. Furthermore, the calculated shares become outdated as the world population steadily grows, thereby constantly decreasing the SoSOS available to each individual. According to the UN, the world population will exceed 11 billion in 2100 (United Nations and Department of Economic and Social Affairs Population Division, 2017), which will decrease the size of sharing principle 1, 2 and 3 drastically, thus inspiring the need for even more ambitious strategies. Nevertheless, it is important to further investigate the sensitivity of the AESA results towards the choice of sharing principle. Moreover, it is recommended to be transparent about choice of sharing principles in AESA and work towards a standardization on the application of sharing principles to increase comparability across AESAs.

It was found that the largest reduction in environmental impact compared to the Base Scenario was achieved in Scenario 1 and Scenario 3, i.e. avoiding an expansion of the house, and lowering the energy consumption by implementing smart technologies and introducing positive nudging to alter the residents' behaviour. Thus, it can be argued that the most important factors towards achieving absolute sustainability are floor area per person and energy consumption per square meter. This is in line with the findings of similar studies (Brejnrod et al., 2017; Ramesh et al., 2010; Sharma et al., 2011).

\section{CONCLUSION}

In this study we have presented an absolute environmental sustainability assessment of six single-family stand-alone dwellings using two methodologies to quantify absolute sustainability. It is found that UP House, Ref House and TMF House is within the boundaries when applying $\mathrm{CC}_{\text {norm }}$ and sharing principle 4 , whereas neither of the assessed dwellings are within the boundaries of absolute sustainability when considering PB-LCIA. AD House, i.e. flexible area, is found to be the worst performing house across both methods and all impact categories, scenarios and sharing principles, whereas Q and UP House, i.e. reduced energy consumption and use of recycled and reused materials respectively, generally are found to be the best performing dwellings. However, when accounting for uncertainty of the LCI, there is not a clear difference in the impact potential for Q and UP house. Thus, it is difficult to conclude which sustainability strategy of the two has the greatest potential to reach absolute sustainability. The conclusions are found to be overall independent of the assessment method applied, but highly dependent on the choice of sharing principle. It is important to note that from the results obtained in this study, achieving absolute sustainability for single-family 
stand-alone dwellings still appears to be out of reach if current practices are not changed. The results call for drastic action in areas such as composition of energy grid mix, choice of materials and way of living. It was found that all parameters considered in this study, which covers a wide range of aspects, had a notable influence on the results. It is however clear that improving in only one area will very likely not be sufficient to achieve absolute sustainability. 


\section{REFERENCES}

Aagaard, N.-J., Brandt, E., Aggerholm, S., Haugbølle, K., 2013. Levetider af bygningsdele ved vurdering af bæredygtighed og totaløkonomi, 1. https://doi.org/10.1016/j.solmat.2010.06.021

Backhaus, J., Breukers, S., Paukovic, M., Mourik, R., Mont, O., 2011. Sustainable lifestyles: Today's facts \& tomorrow's trends.

Bindoff, N.L., Stott, P.A., AchutaRao, K.M., Allen, M.R., Gillett, N., Gutzler, D., Hansingo, K., Hegerl, G., Hu, Y., Jain, S., Mokhov, I.I., Overland, J., Perlwitz, J., Sebbari, R., Zhang, X., 2013. Detection and Attribution of Climate Change: from Global to Regional, in: Stocker, T.F., Qin, D., Plattner, G.-K., Tignor, M., Allen, S.K., Boschung, J., Nauels, A., Xia, Y., Bex, V., Midgley, P.M. (Eds.), Climate Change 2013: The Physical Science Basis. Contribution of Working Group I to the Fifth Assessment Report of the Intergovernmental Panel on Climate Change. Cambridge University Press, Cambridge, United Kingdom and New York, NY, USA, pp. 867-952. https://doi.org/10.1017/CBO9781107415324.022

Bjørn, A., Diamond, M., Owsianiak, M., Verzat, B., Hauschild, M.Z., 2015. Strengthening the link between life cycle assessment and indicators for absolute sustainability to support development within planetary boundaries. Environ. Sci. Technol. 49. https://doi.org/10.1021/acs.est.5b02106

Bjørn, A., Hauschild, M.Z., 2015. Introducing carrying capacity-based normalisation in LCA: framework and development of references at midpoint level. Int. J. Life Cycle Assess. 20, 1005-1018. https://doi.org/10.1007/s11367-015-0899-2

Bjørn, A., Richardson, K., Hauschild, M.Z., 2018. A framework for development and communication of absolute environmental sustainability assessment methods. J. Ind. Ecol. Accepted f, 1-17. https://doi.org/10.1111/jiec.12820

Brejnrod, K.N., Kalbar, P., Petersen, S., Birkved, M., 2017. The absolute environmental performance of buildings. Build. Environ. 119, 87-98. https://doi.org/10.1016/j.buildenv.2017.04.003

Cabeza, L.F., Rincón, L., Vilariño, V., Pérez, G., Castell, A., 2014. Life cycle assessment 
(LCA) and life cycle energy analysis (LCEA) of buildings and the building sector: A review. Renew. Sustain. Energy Rev. 29, 394-416.

https://doi.org/10.1016/j.rser.2013.08.037

CEN, 2011. EN 15978:2011 Sustainability of construction works - Assessment of environmental performance of buildings - Calculation method.

Climate Change 2014: Synthesis Report. Contribution of Working Groups I, II and III to the Fifth Assessment Report of the Intergovernmental Panel on Climate Change [Core Writing Team, R.K. Pachauri and L.A. Meyer (eds.)]. IPCC, Geneva, Switzerland, 151 pp.

Cohen, P., West, S.G., Aiken, L.S., 2014. Applied Multiple Regression/Correlation Analysis for the Behavioral Sciences, 2nd ed. Taylor and Francis.Dansk Standard, 2012. DS/EN 15978: Bæredygtighed inden for byggeri og anlæg - Vurdering af bygningers miljømæssige kvalitet - Beregningsmetode.

Desmit, X., Thieu, V., Billen, G., Campuzano, F., Dulière, V., Garnier, J., Lassaletta, L., Ménesguen, A., Neves, R., Pinto, L., Silvestre, M., Sobrinho, J.L., Lacroix, G., 2018. Reducing marine eutrophication may require a paradigmatic change. Sci. Total Environ. 635, 1444-1466. https://doi.org/10.1016/j.scitotenv.2018.04.181

DK-GBC, Green Building Council Denmark, 2018. Cirkulær økonomi og DGNB - Guide til cirkulære principper i DGNB bæredygtighedscertificering

European Commission. Energy performance of buildings https://ec.europa.eu/energy/en/topics/energy-efficiency/energy-performance-ofbuildings. [Accessed: 25-Apr-2019]

European Standard, 2008. ISO 14040: Environmental management- Life cycle assessment Principles and framework.

European Standard, 2006. ISO 14044: Environmental management- Life cycle assessment Requirements and guidelines.

Ecoinvent, 2019. Ecoinvent version 3

Hauschild, M.Z., 2015. Better - But is it Good Enough? On the Need to Consider Both Eco- 
efficiency and Eco-effectiveness to Gauge Industrial Sustainability. Procedia CIRP 29, 1-7. https://doi.org/10.1016/j.procir.2015.02.126

Hauschild, M.Z., Rosenbaum, R.K., Olsen, S.I., 2018. Life Cycle Assessment - Theory and Practice. Springer International Publishing.

Häyhä, T., Lucas, P.L., van Vuuren, D.P., Cornell, S.E., Hoff, H., 2016. From Planetary Boundaries to national fair shares of the global safe operating space - How can the scales be bridged? Glob. Environ. Chang. 40, 60-72. https://doi.org/10.1016/j.gloenvcha.2016.06.008

Lucas, P.L., Wilting, H.C., Hof, A.F., van Vuuren, D.P., 2020. Allocating planetary boundaries to large economies: Distributional consequences of alternative perspectives on distributive fairness. Glob. Environ. Chang. 60, 102017. https://doi.org/10.1016/j.gloenvcha.2019.102017

Maslesa, E., Jensen, P. A., Birkved, M., 2018. Indicators for quantifying environmental building performance: A systematic literature review. Journal of Building Energy, Vol 19, 552-560. https://doi.org/10.1016/j.jobe.2018.06.006

Owsianiak, M., Bjørn, A., Bugge, H.B., Carvalho, S.M., Jebahar, L., Rasmussen, J., White, C.M., Olsen, S.I., 2018. Chapter 39: Illustrative Case Study: Life Cycle Assessment of Four Window Alternatives, in: Life Cycle Assessment, Theory and Practice.

PRé, 2019. SimaPro, the world's leading sustainability software

Ramesh, T., Prakash, R., Shukla, K., 2010. Life cycle energy analysis of buildings: an overview. Energy and Buildings.

Rasmussen, F. N., Birkved, M., \& Birgisdóttir, H. (2019). Low carbon design strategies for new buildings - lessons from Danish architectural practice. Under review in Architectural Engineering and Design Management.

Realdania Byg, Kleis, B., 2014a. Det Vedligeholdelsesfrie Hus - fornyelse fortolker fortiden. Realdania Byg, Kleis, B., 2014b. Kvotehuset - sætter beboerne i spil.

Realdania Byg, Kleis, B., 2013a. Det Foranderlige Hus - Bygget til at bygge om. 
Realdania Byg, Kleis, B., 2013b. Upcycle House - genbrug fra inderst til yderst.

Realdania Byg, Leth \& Gori, 2014. De Vedligeholdelsesfri Huse - Traditionen, Det murede hus, evaluering af forsøgsprojekt.

Rockstrom, J., 2009. A safe operating space for humanity. Nature 461, 472-475. https://doi.org/10.1109/TIP.2011.2165549

Rockström, J., Steffen, W.L., Noone, K., et al, 2009a. Planetary boundaries: exploring the safe operating space for humanity. Ecol. Soc. 14, 32.

Rockström, J., Steffen, W.L., Noone, K., Persson, Å., Chapin III, F.S., 2009b. Planetary Boundaries: Exploring the safe operating space for humanity. Uma ética para quantos? XXXIII, 81-87. https://doi.org/10.1007/s13398-014-0173-7.2

Ryberg, M.W., 2018. Putting life-cycle indicators on an absolute scale - Integrating Planetary Boundaries into Life-Cycle Assessment.

Ryberg, M.W., Owsianiak, M., Clavreul, J., Mueller, C., Sim, S., King, H., Hauschild, M.Z., 2018a. How to bring absolute sustainability into decision-making: An industry case study using a Planetary Boundary-based methodology. Sci. Total Environ. 634, 14061416. https://doi.org/https://doi.org/10.1016/j.scitotenv.2018.04.075

Ryberg, M.W., Owsianiak, M., Hauschild, M.Z., 2018b. Review of principles for assigning shares of the safe operating space to anthropogenic activities for absolute sustainability assessments in an LCA-context.

Ryberg, M.W., Owsianiak, M., Laurent, A., Hauschild, M.Z., 2015. Power generation from chemically cleaned coals: do environmental benefits of firing cleaner coal outweigh environmental burden of cleaning? Energy Environ. Sci. 2435-2447. https://doi.org/10.1039/C5EE01799H

Ryberg, M.W., Owsianiak, M., Richardson, K., Hauschild, M.Z., 2018c. Development of a life-cycle impact assessment methodology linked to the Planetary Boundaries framework. Ecol. Indic. 88, 250-262. https://doi.org/10.1016/j.ecolind.2017.12.065

Ryberg, M.W., Owsianiak, M., Richardson, K., Hauschild, M.Z., 2016. Challenges in implementing a Planetary Boundaries based Life-Cycle Impact Assessment 
Methodology. J. Clean. Prod. 139, 450-459.

https://doi.org/10.1016/j.jclepro.2016.08.074

Sala, S., Benini, L., Crenna, E., Secchi, M., 2016. Global environmental impacts and planetary boundaries in LCA. https://doi.org/10.2788/64552

Sandin, G., Peters, G.M., Svanström, M., 2015. Using the planetary boundaries framework for setting impact-reduction targets in LCA contexts. Int. J. Life Cycle Assess. 20, 1684-1700. https://doi.org/10.1007/s11367-015-0984-6

Sharma, A., Saxena, A., Sethi, M., Shree, V., 2011. Life cycle assessment of buildings: a review.

Steffen, W., Broadgate, W., Deutsch, L., Gaffney, O., Ludwig, C., 2015a. The trajectory of the Anthropocene: The Great Acceleration. Anthr. Rev. https://doi.org/10.1177/2053019614564785

Steffen, W., Richardson, K., Rockström, J., Cornell, S.E., Fetzer, I., Bennett, E.M., Biggs, R., Carpenter, S.R., de Vries, W., de Wit, C.A., Folke, C., Gerten, D., Heinke, J., Mace, G.M., Persson, L.M., Ramanathan, V., Reyers, B., Sorlin, S., 2015b. Planetary boundaries: Guiding human development on a changing planet. Science (80-. ). 347, 736. https://doi.org/10.1126/science. 1259855

Steffen, W., Richardson, K., Rockström, J., Cornell, S.E., Fetzer, I., Bennett, E.M., Biggs, R., Carpenter, S.R., de Vries, W., de Wit, C.A., Folke, C., Gerten, D., Heinke, J., Mace, G.M., Persson, L.M., Ramanathan, V., Reyers, B., Sorlin, S., 2015c. Planetary boundaries: Guiding human development on a changing planet. Science (80-. ). 347, 1217. https://doi.org/10.1126/science.1259855

Steffen, W., Sanderson, A., Tyson, P., Jäger, J., Matson, P., 2004. Global Change and the Earth System.

United Nations, Department of Economic and Social Affairs Population Division, 2017. World Population Prospects: The 2017 Revision, Key Findings and Advance Tables.

Vanderheiden, S., 2009. Allocating ecological space. J. Soc. Philos. 40, 257-275. https://doi.org/10.1111/j.1467-9833.2009.01450.x 
Østergaard, N., Thorsted, L., Miraglia, S., Birkved, M., Rasmussen, F.N., Birgisdóttir, H., Kalbar, P., Georgiadis, S., 2018. Data Driven Quantification of the Temporal Scope of Building LCAs. Procedia CIRP 69, 224-229.

https://doi.org/10.1016/j.procir.2017.11.057 